\title{
Using University-Community Partnerships to Stem Environmental Inequities and Injustice
}

\author{
Ralph Gallo (Corresponding author) \\ College of Humanities \& Social Sciences, College of Criminal Justice, Sam Houston \\ State University \\ P.O. Box 2446, Huntsville, Texas 77341, United States \\ Tel: 1-936-294-1512Ｅ-mail: jrg050@shsu.edu
}

\begin{abstract}
Consuela Amos
College of Educational Leadership \& Counseling, Prairie View A\&M University

P.O. Box 519, Prairie View, Texas 77446, United States

Tel: 1-936-261-3600_E-mail: camos101@yahoo.com
\end{abstract}

Received: April 25, 2013 Accepted: May 23, 2013 Published: May 27, 2013

doi:10.5296/ijssr.v1i1.3588 URL: http://dx.doi.org/10.5296/ijssr.v1i1.3588

\begin{abstract}
The purpose of this paper, therefore, is to discuss the roots of the movement by reviewing the following: (1) theoretical perspective of community engagement, (2) the environmental justice movement and (3) the challenges of the environmental justice movement that can be addressed through effective collaborations between universities and the communities they serve. A survey design was used to collect and analyze the data. Two hundred out of four hundred and twenty five participants elected to participate in this study. Statistically significant differences were found in the perceptions regarding exposure to environmental waste, preventive technology, community resources, personal access to technology, community lab access, computer training classes and empowerment through technology.
\end{abstract}

Keywords: Environmental Justice, Community Engagement, Community Resources, University-Community Collaborations 


\section{Introduction}

Town-gown relationships, also known as collaborations between the university and the community, have continued to receive acknowledgement of its ability to enhance the benefits to the community, especially between white universities and African American communities (Bombyk, Ohren, \& Shue, 2003; Rowson, Broome, \& Jones, 2010). Universities interact with the community to improve the relationship by realizing that the community knows what its problems are but lack resources to properly address those needs The university, in turn, can match the resources to fit the communities' needs along with guiding the community in the process of being empowered with the knowledge and proper tools to address future needs (Young, 1995; Onyx, 2008).

To further solidify the need for universities to become involved in community engagement, Isaac indicates (2003, pp. 8), "There is a strong need for citizen involvement concerning priorities, problems, and political solutions because the community knows what the problems are; however, the citizens may not know the resources available to solve them." The Council for International Development (2003) defined advocacy planning theory as a "People-centered advocacy that involves the affected communities themselves in advocating for change as participants in the process, not as objects of the process" (Isaac, 2003, pp. 8).

The purpose of this paper, therefore, is to discuss the roots of the movement by reviewing the following: (1) theoretical perspective of community engagement, (2) the environmental justice movement and (3) the challenges of the environmental justice movement that can be addressed through effective collaborations between universities and the communities they serve.

\section{Theoretical Perspective of Community Engagement}

An important aspect of advocacy planning is equity planning theory. Because equity planning theory discusses making changes from within, the university would need to take this approach to build trust between the university and the community. Fainstein and Campbell (2003) discussed the value of equity planning theory thus:

"Equity planning emerged as a less combative form of advocacy planning that allowed planners to serve the interest of the poor from within the system" (Campbell \& Fainstein, 2003a, p. 9).

To be sure, research by Bombyk, Ohren, \& Shue (2003) suggest that universities should utilize its employees who are also residents of the community to sit on community boards as well as to make up community organizations, therefore, being a representative that understands the needs of the community as well as the limitations of the university.

"Furthermore, equity planning promotes the idea of creating an equal distribution of knowledge and resources while also promoting, in many cases, economic capital. Universities can stimulate this practice into growth for the community that will be realized in the form of a greater tax base, larger percentages of homeowners, and increases in job opportunities" (Bombyk, Ohren, \& Shue, 2003, pp. 25-26). 
In effect, the university would help the community address needs identified by its residents and leaders, and would encourage the community to become involved in the decision-making process from the onset of collaboration. The partnership would thus allow for establishing a good working relationship that encourages faculty, staff, and residents to become more involved on an informal level. Furthermore, the partnership can further enable both the university and the community to participate in the redevelopment process of their communities (Campbell \& Fainstein, 2003).

The knowledge that the community residents hold about their problems is indeed valuable and should not be ignored. Therefore, community leaders, residents, and university leaders should make every attempt to build their relationship by encouraging community involvement while making certain that residents of the community are well informed about the work between the university and community (Reid, 2000).

The university, community leaders, and residents should operate with an open mind and respect each other's view points (Reardon, 2005). Also, universities and communities should be encouraged to place themselves in a position to garner full participation from community residents by assessing the residents' level of knowledge about programs offered by the university, by identifying the community's needs and priorities, and by accessing the resources offered by the university to their community. In short, the university helping the community to define its mission may allow the university to redefine its own mission (Bombyk, Ohren \& Shue, 2003).

Davidoff (1965) stated that if planning was a true democratic process, then an inclusive approach needed to be used whereby the citizen would be encouraged to become more involved in the planning process by becoming as informed as possible. Advocacy planning theory can be used as a catalyst to stimulate the knowledge of citizens so they will be in a position to make more informed decisions for their community, decisions that would best meet their needs (Campbell \& Fainstein, 2003).

Davidoff's approach, with university-community-partnerships, would most aptly be used in the environmental justice movement where historically poor and/or minority communities have unjustly been exposed to toxins, hazardous waste materials and landfills because of the strong correlation between socioeconomic status and overrepresentation of hazardous waste facilities (Cutter, Holm, \& Cark, 1996; Elliott et al., 2009). Research has visited the question of toxic and hazardous waste facilities. The concern has been to what extent these communities find themselves bearing a disproportionate amount of the burden (Oakes, Anderton, \& Anderson, 1996; Demery, Petts, Walker \&Smith, 2007; Kearney \& Kiros, 2009). More recently, an international study revealed that there indeed is a correlation between ethnic minorities, socioeconomic status and waste facility siting in their communities (Martuzzi, Mitis \& Forasteire, 2010). To further parallel supported research, Hill (2009) indicates that Arkansas was the first state to pass legislation for compensation to communities for environmental waste. This legislation was passed to prevent overrepresentation of solid waste disposal facilities in low income and minority communities, however, these communities are still faced with bearing the brunt of the burden. 


\section{The Environmental Justice Movement}

The environmental justice movement addresses the unequal distribution of goods and services; however, there are factors that constrain the ability to ensure all goods and services are distributed properly. In the effort to describe environmental justice, the example of equal distribution of public goods will be utilized. Public goods can be defined as jointed, meaning that it could be evenly distributed and consumed by more than one person at any given time and one person's use of the good does not prohibit the use of another (Campbell \& Fainstein, 2003).

When there is a threat to resources i.e. clean water, clean air, a conflict arises. Bullard et al. (2007) found that even today, minority, low-income families are more likely to be targets of environmental justice then they were found in the 1987 Toxic Wastes and Race report. An example of this is reported by Bullard (2000) where a 1992 study revealed that there were "glaring inequities" in the way the Environmental Protection Agency (EPA) enforced its laws in minority communities as opposed their white counterparts. In addition, penalties imposed in white communities were stiffer than those imposed in minority communities (Bullard, 2000). Previous presidential administrations advocated for stricter enforcement on environmental offenders; however, this ground was lost during later administrations. A plausible argument is poor and minority communities generally do not have the representation in city government or on other non-government agencies such as the Sierra Club and Green Peace. This lack of equal representation is the underlying cause for why there have been continued instances of environmental injustices. Until there is equal representation, the struggle for equality will continue (Elmendorf \& Rios, 2008).

Yet another cause for struggle is the concept of Not in My Backyard (NIMBY) and Locally Unwanted Land Uses (LULUs), which has been a constant in environmental justice. It addresses the fact that there will be hazardous waste, garbage dumps, polluting industries, and incinerators that will eventually end up in someone's back yard. Many civil organizations against NIMBYs have questioned land uses that will affect lives and communities as well as empowered individuals to stand up for themselves (Saint, Flavell \& Fox, 2009).

A factor associated with the NIMBY syndrome is job blackmail. This occurs when toxic/hazardous waste facilities state that their company will provide job opportunities to the community when in reality, there will be few, if any jobs available. Of the jobs that will be available to the community, they are normally low paying requiring minimal education. The preponderance of the jobs are given to individuals who live outside of the community and are better trained, thus creating yet another source of conflict where there is a distinct delineation between social classes (Saint, Flavell, \& Fox, 2009; Baibergenova, Kudyakov, Zdeb, \& Carpenter, 2003).

\section{Challenges of Environmental Justice}

\subsection{Historical Implications}

Houston, Texas was named the petrochemical capitol of the world in the 1970s. The city's prosperity windfall came from being heavily invested in petrochemical companies. At that 
time, the issues of exploitation that were facing many other black communities across the nation were affecting Houston's minority communities as well. The city faced strong criticism because of its preference of subdivision regulations over zoning laws. This later posed a greater conflict in areas where deed restrictions lapsed allowing opportunities for encroachment. Most notably, the areas where there was a notable lapse of restrictions were poor and minority communities. Historically, these communities have to shoulder a disproportionately large share of garbage dumps, landfills, salvage yards and many other LULU facilities. The resulting effect was fueled by tension between the local government and poor and minority communities who felt their communities were unfairly targeted (Bullard, 2000).

Northwood Manor, also located in Houston, Texas, was a community comprised of 8,500 residents with approximately $83 \%$ percent being black and single family home owners. Additionally, it is located in one of the poorest school districts in Houston. North Forest Independent School District had controversly come to this community when a proposed Whispering Pines Landfill was to be built in the Northwood Manor neighborhood. The community was misled into believing construction was for a new subdivision when, in reality, it was for a landfill. The community organized and filed a lawsuit against Whispering Pines Landfill. When it went to court, the judgment in the case was in favor of the landfill. Amidst the negativity generated by the case, the major benefits that were gained were created by the outcry of similar communities to pressure the city of Houston to pass a resolution in 1980 to prohibit city-owned trucks from carrying solid waste from dumping at the controversial landfill. Secondly, an ordinance was passed restricting the construction of solid waste near public facilities such as schools. Yet another reason for the positive input is the Texas Department of Health came up with more stringent requirements for landfill permits (Bullard, 2000).

The following locations are all black communities that either have an incinerator or a landfill; in some cases there are both: Fourth Ward, Cottage Grove, Kashmere Gardens, Sunny Side, Navigation, Larchmont, Carvendale, Trinity Gardens, Acres Homes, Holmes Road, McCarty, and Whispering Pines (Bullard, 2000). The cases in Houston, Texas indicate that for a length of time that it was an excepted practice to exploit the areas of least resistance. In most instances it has always been the minority and poor communities. If one travels through Houston today, one can still see the remnants of old landfills and incinerators.

Alsen, Louisiana, nestled right outside Baton Rouge, became the central focus for hazardous waste incinerators. Its pollutants from burned materials were found as the cause of illness in the community. Most significant is the community's proximity to cancer alley, a 140 mile stretch between Baton Rouge and New Orleans on the Mississippi River lined with hazardous waste facilities (Bullard, 2000). This case, however, is not isolated. There are counties in other states such as Button Willow and Cattleman City, California. These are Hispanic communities who have to contend with the same issues as African Americans in many other cities and states across the U.S. Injustice is a common denominator among minorities of all races. It also confirms that environmental justice cases are more prevalent among low income communities that are more susceptible to being preyed upon by big companies (Cole \& 
Foster, 1993).

\subsection{Recent Cases}

While there have been some progress in the environmental justice movement, the struggle is far from over as evidenced by recent cases in Dickson County, Tennessee and New Orleans, Louisiana. Indeed, socioeconomic status has proven to be the common denominator in each of these cases. Moreover, when injustices were found in white communities, they were more apt to be compensated over their non-white counterparts (Martuzzi, Mitis, \& Forastiere, 2010). According to U.S. Census (2010), the African American population in Dickson County is 4.4 percent, comprised mostly in the Eno Road community. The town evolves from its history as being purchased for a city dump in 1946. The dump was opened between 1946 and 1956 as an unlined facility. The dump's property was adjacent to the Old Negro Coaling School, and after the 1987 expansion, the Holt family homestead. For many years, toxic industrial waste solvents were dumped at this unlined landfill, which resulted in contaminated groundwater.

The Holt family has a long familial ancestry in the Eno Road community and the homestead's well is just fifty four feet from the property line of the dump site that has been identified as the source of contamination for neighboring wells. White citizens of the community were connected to city services, had new wells dug and were given drinking water to drink and cook with until the water could be deemed safe. Moreover, all of this information was outlined in written correspondence to inform white families of future plans to rectify the problems with the contamination. In stark contrast, it took twelve years and Harry Holt's passing away before the African American family was told that their well was contaminated. No one offered to connect the family to city water services, bottled water for drinking and cooking nor an explanation of why the family was getting sick. Further impacting the situation, the Dickson County Commissioners agreed to settle lawsuits with the white residents that alleged that their groundwater was contaminated from a leaky landfill in November 2006. Both the county and the city have agreed to these families $75 \%$ of the monies received from a lawsuit against the company that owns the landfill. This case is still pending an outcome in court (U.S. EPA).

Another recent case that America watched in horror is the tragedy that hit New Orleans with Hurricane Katrina. In 2007, the EPA and Louisiana Department of Environmental Quality (LDEQ) estimated that 140,000 to 160,000 homes needed to be abolished or disposed of in addition to 100 million cubic yards of debris generated from the storm. Additionally because of the amount of toxic waste, the area was considered as the "mother of all toxic cleanups" (Bullard, Mohai, Saha, \& Wright, 2007, p. 125). This reference became a mantra when it was determined that approximately 350,000 automobiles had to be drained of oil and gas for recycling, 60,000 boats must be destroyed, 300,000 underground fuel tanks and 42,000 tons of hazardous waste had to be cleaned up and disposed at the proper facilities.

A solution to the growing problem of creating a place to properly dispose of the aforementioned toxic waste (Damery et al., 2007) was proposed by LDEQ to reopen the unlined 200 acre Gentilly Landfill that had been ordered closed in the 1980s. Considering 
that the landfill operated as a construction and demolition site, it was unnecessary to have a liner. However in 2006 when the facility reopened despite the protest of environmentalists, more than 2,000 truckloads of debris were being disposed at the site daily. Residents and environmentalists in the area filed a lawsuit to block further dumping at the site due to the allegation that toxic waste was being disposed at the site that could contaminate groundwater. Just four days after the filing, the landfill caught fire (U.S. EPA).

Gintilly was no longer considered a solution to the growing problem, so the U.S. Army Corps of Engineers in conjunction with LDEQ determined that Waste Management, Inc. could open and operate a construction and demolition landfill in New Orleans East, a predominately African American section of the city. Moreover, LDEQ allowed possibly contaminated material to be disposed. When posed with this concern, LDEQ responded in kind by stating that contamination of the debris is insignificant as to cause pollutants to the environment (Damery et al., 2007). Nonetheless, there is great concern for environmental contamination due to the landfill not having a liner to prevent toxic seepage (Bullard, Mohai, Saha, \& Wright, 2007).

\section{Methodology}

\subsection{Sampling Procedures}

A survey design was used to collect and analyze the data. All civic associations or clubs with memberships of 50 or more residents in the communities of Fourth Ward, Cottage Grove, Kashmere Gardens, Sunny Side, Navigation, Larchmont, Carvendale, Trinity Gardens, Acres Homes, Holmes Road, McCarty, Fifth Ward and Whispering Pines were identified. Once the list of residents was provided, the researchers assigned a code from 01 to $\mathrm{N}$, where the $\mathrm{N}$ is the total number of residents in the associations or clubs. The table of random numbers was used to select the residents. Two hundred out of four hundred and twenty five participants elected to participate in this study. To eliminate response bias, surveys arrived over a period of five weeks and involved the mailing of a reminder note. One would argue that late respondents more closely resembled non-respondents, in which case, if a response bias exists, late respondents would differ from early respondents. Accordingly, respondents were grouped by arrival date and the dependent variables were compared using One-Way Analysis of Variance. No significant differences were observed. The instrument entitled "Gallo-Amos Community Perception Instrument" was used to collect the data. The data was used to examine the perception of income level and its impact on environmental waste facilities in the community, preventive technology, community access to technology, personal access to technology away from work, community center or local library with computer lab access, computer classes being offered at the community center or local library and encouragement of minorities and the poor to technology for empowerment against environmental justice. The One-Way Analysis of Variance and the Scheffé Multiple Comparison Test were used to analyze the data. 


\subsection{Validity and Reliability}

To establish validity, the researcher submitted the Community Perception Instrument to a group of authorities in environmental justice as well as in evaluation and research, and asked them to determine the degree to which the items on the survey measured the appropriateness of the survey. All members of the validation team were asked to assess the validity of each item according to their specific responses, which were scored from zero to two (0-2), with zero meaning the statement was valid and measured what it was supposed to measure. Once the authorities agreed that the Community Perception Instrument was a valid instrument for the present study, the researcher conducted a pilot test of the instruments (Marshall \& Rossman, 2011).

For the purpose of determining reliability, the researcher employed the Split-Half Procedure. This method involved correlating scores of even numbered items. The Split-Half procedure assessed reliability for half of the test. The Spearman-Brown Formula was used in conjunction with the Split-Half coefficient to compute reliability. Coefficient of .70 is needed for an instrument to be considered reliable (Marshall \& Rossman, 2011). A Split-Half reliability coefficient of .741 was computed when the Spearman-Brown formula was applied to the Split-Half Procedure. A reliability of .772 was calculated for the test as a whole.

\section{Analysis of Results}

\subsection{Descriptive Data}

The descriptive statistics of the participants revealed there were twenty two (11\%) male participants and one hundred seventy eight (89\%) female participants. The racial demographics revealed that while there were five categories to choose from, only three were selected. One hundred six (53\%) participants identified themselves as African American, seventy (35\%) Hispanic and twenty four (12\%) white. Similarly, age has seven categories; however, the participants self-reported age in four categories. There were thirty $(15 \%)$ participants who were between the ages of twenty and thirty; one hundred one $(50.5 \%)$ were between thirty one and forty. In addition, 37 (18.5\%) participants reported their age as forty one through fifty, and thirty two (15\%) said they were fifty one through sixty.

Regarding the participants' level of education, eleven (5.5\%) reported graduating from high school or earning a GED and twenty five $(12.5 \%)$ had some college. On the other hand, ninety one $(45.5 \%)$ participants completed their associate's degree, forty four (44\%) said they completed their bachelor's degree and twenty nine (14.5\%) reported earning their master's degree. Relative to the annual incomes of the participants, forty nine $(24.5 \%)$ of them reported their incomes less than $\$ 20,000$, and fifty seven $(28.5 \%)$ revealed their income as being between $\$ 20,000$ and $\$ 30,000$. Additionally, forty nine $(24.5 \%)$ participants identified their income as $\$ 31,000$ to $\$ 40,000$, thirty one (15.5\%) indicated their income was $\$ 41,000$ to $\$ 50,000$ and fourteen $(7 \%)$ reported their income over $\$ 51,000$. 
6.2 Exposure to Environmental Waste

Table 1. Analysis of variance summary table impact of education on exposure to environmental waste

\begin{tabular}{lllrcrrr}
\hline & \multicolumn{1}{c}{$\begin{array}{c}\text { Source of } \\
\text { Variance }\end{array}$} & $\begin{array}{c}\text { Sum of } \\
\text { Squares }\end{array}$ & df & Mean Square & F & Sig. \\
Exposure to & Between Groups & 34.287 & 4 & 34.830 & 15.347 & $.000 *$ \\
Environmental & Within Groups & 108.908 & 195 & .559 & & \\
Waste & Total & 143.195 & 199 & & & \\
\hline
\end{tabular}

*significant at the .05 level.

Participants were asked to respond if they felt their income level impacted whether or not they lived in a community with environmental waste. Presented in Table 1 are the Analysis of Variance results pertaining to the perceptions of community members regarding the impact of income level on environmental waste located in their community. As revealed in this table, statistically significant differences were found among the community members with regard to level of education and exposure to environmental waste $(\mathrm{F}=15.347, d f=4 / 195, p>.05)$ at the .05 level.

Table 2. Scheffé results of exposure to environmental waste by level of education

\begin{tabular}{ccccccc}
\hline $\begin{array}{c}\text { Mean 1 } \\
\text { Completed } \\
\text { High School }\end{array}$ & $\begin{array}{c}\text { Mean 2 } \\
\text { Some } \\
\text { College }\end{array}$ & $\begin{array}{c}\text { Mean 3 } \\
\text { Associate's } \\
\text { Degree }\end{array}$ & $\begin{array}{c}\text { Mean 4 } \\
\text { Bachelor's } \\
\text { Degree }\end{array}$ & $\begin{array}{c}\text { Mean 5 } \\
\text { Master's } \\
\text { Degree }\end{array}$ & $\begin{array}{c}\text { Observed } \\
\text { Mean } \\
\text { Differences }\end{array}$ & p \\
\hline 1.82 & 2.92 & & & & $-1.102 *$ & $.003^{*}$ \\
1.82 & & 1.88 & & & -.061 & .999 \\
1.82 & & & 1.73 & & .091 & .998 \\
1.82 & & & & 1.41 & .404 & .675 \\
\hline
\end{tabular}

*significant at the .05 level.

Since the Analysis of Variance indicated significance but did not reveal where the differences were, the Scheffé Test was used. Further data analysis using the Scheffé Multiple Comparison Test revealed that the community residents' level of education as impacting community resident's exposure to environmental waste (See Table 2). In fact, the Scheffé reveals that residents who had less than an associate's degree were more likely to live in a community with an environmental waste facility than those with higher degrees. 
6.3 Preventive Technology

Table 3. Analysis of variance summary table impact of level of education on preventive technology

\begin{tabular}{llccccc}
\hline & \multicolumn{1}{c}{$\begin{array}{c}\text { Source of } \\
\text { Variance }\end{array}$} & $\begin{array}{c}\text { Sum of } \\
\text { Squares }\end{array}$ & $\boldsymbol{d f}$ & Mean Square & F & Sig. \\
Preventive & Between Groups & 45.335 & 4 & 11.334 & 26.328 & $.000^{*}$ \\
Technology & Within Groups & 83.945 & 195 & .430 & & \\
& Total & 129.280 & 199 & & & \\
\hline
\end{tabular}

*significant at the .05 level.

Reported in Table 3 are the results of community residents' perception of level of education with respect to access to technology that could aid residents in fighting against waste companies targeting their community. Statistically significant differences were found between the means of education level and preventive technology $(\mathrm{F}=26.328, d f=4 / 195, p>.05)$ at the .05 level.

Table 4. Scheffé results of preventive technology by level of education

\begin{tabular}{ccccccc}
\hline $\begin{array}{c}\text { Mean 1 } \\
\text { Completed } \\
\text { High }\end{array}$ & $\begin{array}{c}\text { Mean 2 } \\
\text { Some } \\
\text { College }\end{array}$ & $\begin{array}{c}\text { Mean 3 } \\
\text { Associate's } \\
\text { Degree }\end{array}$ & $\begin{array}{c}\text { Mean 4 } \\
\text { Bachelor's } \\
\text { Degree }\end{array}$ & $\begin{array}{c}\text { Mean 5 } \\
\text { Master's } \\
\text { Degree }\end{array}$ & $\begin{array}{c}\text { Observed } \\
\text { Mean } \\
\text { Differences }\end{array}$ & p \\
2.09 & 3.00 & & & & $-.909^{*}$ & $.007^{*}$ \\
2.09 & & 2.76 & & & $-.667^{*}$ & $.041^{*}$ \\
2.09 & & & 2.14 & & -.045 & 1.000 \\
2.09 & & & & 1.55 & .539 & .254 \\
\hline
\end{tabular}

*significant at the .05 level.

Scheffé Multiple Comparison Test revealed that there was a relationship between the means of completed high school and some college. In essence, community residents with this level of education were more likely to perceive that there was not enough done to utilize technology to prevent communities from being targeted for environmental waste. See Table 4 for the results. 
6.4 Community Resources

Table 5. Analysis of variance summary table impact of level of education on community resources

\begin{tabular}{ccllccc}
\hline \multirow{2}{*}{ Source of Variance } & Sum of Squares & $\boldsymbol{d f}$ & Mean Square & F & Sig. \\
Community & Between Groups & 23.792 & 4 & 5.948 & 6.685 & $000^{*}$ \\
Access & Within Groups & 173.488 & 195 & .890 & & \\
& Total & 197.280 & 199 & & & \\
\hline
\end{tabular}

*significant at the .05 level.

The One Way Analysis of Variance was also computed for the variable access to all other community resources to include university partnerships. Table 5 indicates that there was a statistically significant difference among the groups of community residents, specifically there was a significance between level of education and access to community resources $(\mathrm{F}=$ $6.685, d f=4 / 195, p>.05$ ) at the .05 level.

Table 6 . Scheffé results of community resources by level of education

\begin{tabular}{ccccccc}
\hline $\begin{array}{c}\text { Mean 1 } \\
\text { Completed } \\
\text { High } \\
\text { School }\end{array}$ & $\begin{array}{c}\text { Mean 2 } \\
\text { Some } \\
\text { College }\end{array}$ & $\begin{array}{c}\text { Mean 3 } \\
\text { Associate's } \\
\text { Degree }\end{array}$ & $\begin{array}{c}\text { Mean 4 } \\
\text { Bachelor's } \\
\text { Degree }\end{array}$ & $\begin{array}{c}\text { Mean 5 } \\
\text { Master's } \\
\text { Degree }\end{array}$ & $\begin{array}{c}\text { Observed } \\
\text { Mean } \\
\text { Differences }\end{array}$ & P \\
\hline 3.82 & 3.40 & & & & -.127 & .614 \\
3.82 & & 2.78 & & & .493 & .080 \\
3.82 & & & 2.98 & .318 & .907 \\
3.82 & & & & 3.72 & -.451 & $.000^{*}$ \\
\hline
\end{tabular}

*significant at the .05 level

Scheffé showed a statistically significant difference between the means of high school and master's degree as indicated by Table 6 . The results revealed that residents with a master's degree perceived that level of education has an impact on accessing community resources than those with lesser education. 
6.5 Personal Access to Technology

Table 7. Analysis of variance summary table impact of level of education on personal access to technology

\begin{tabular}{llllllll}
\hline & Source of Variance & $\begin{array}{l}\text { Sum of } \\
\text { Squares }\end{array}$ & $\boldsymbol{d f}$ & $\begin{array}{l}\text { Mean } \\
\text { Square }\end{array}$ & F & Sig. \\
Personal & Between Groups & 30.689 & 4 & 7.672 & 7.796 & $.000^{*}$ \\
Access to & Within Groups & 191.906 & 195 & .984 & & \\
Technology & Total & 222.595 & 199 & & & \\
\hline
\end{tabular}

*significant at the .05 level.

Table 8. Scheffé results of personal access to technology by level of education

\begin{tabular}{ccccccc}
\hline $\begin{array}{c}\text { Mean 1 } \\
\text { Completed } \\
\text { High } \\
\text { School }\end{array}$ & $\begin{array}{c}\text { Mean 2 } \\
\text { Some } \\
\text { College }\end{array}$ & $\begin{array}{c}\text { Mean 3 } \\
\text { Associate's } \\
\text { Degree }\end{array}$ & $\begin{array}{c}\text { Mean 4 } \\
\text { Bachelor's } \\
\text { Degree }\end{array}$ & $\begin{array}{c}\text { Mean 5 } \\
\text { Master's } \\
\text { Degree }\end{array}$ & $\begin{array}{c}\text { Observed } \\
\text { Mean } \\
\text { Differences }\end{array}$ & p \\
3.64 & 2.28 & & & & 1.356 & $.001 *$ \\
3.64 & & 2.45 & & & 1.186 & $.002 *$ \\
3.64 & & & 2.75 & & .886 & .062 \\
3.64 & & & & 1.24 & 2.395 & $.000 *$ \\
\hline
\end{tabular}

*significant at the .05 level.

As indicated by Table 7, a statistically significant relationship was found with level of education and personal access to technology away from work $(\mathrm{F}=7.796, d f=4 / 195, p>.05)$ at the .05 level. Upon running the Scheffé (Table 8), the data revealed that community residents who completed high school, held an associate's or master's degree viewed level of education as being more effective in their ability to have personal access to technology away from work than residents with a bachelor's degree. 
6.6 Community Lab Access

Table 9. Analysis of variance summary table impact of level of education on community lab access

\begin{tabular}{llccccc}
\hline & \multicolumn{1}{c}{$\begin{array}{c}\text { Source of } \\
\text { Variance }\end{array}$} & $\begin{array}{c}\text { Sum of } \\
\text { Squares }\end{array}$ & df & $\begin{array}{c}\text { Mean } \\
\text { Square }\end{array}$ & F & Sig. \\
Community Lab & Between Groups & 37.230 & 4 & 9.307 & 7.824 & $.000^{*}$ \\
Access & Within Groups & 231.965 & 195 & 1.190 & & \\
& Total & 269.195 & 199 & & & \\
\hline
\end{tabular}

*significant at the .05 level.

Table 10. Scheffé Results of Community Lab Access by Level of Education

\begin{tabular}{ccclccc}
\hline $\begin{array}{c}\text { Mean 1 } \\
\text { Completed } \\
\text { High } \\
\begin{array}{c}\text { School } \\
\text { Some }\end{array}\end{array}$ & $\begin{array}{c}\text { Mean 2 } \\
\text { College }\end{array}$ & $\begin{array}{c}\text { Mean 3 } \\
\text { Associate's } \\
\text { Degree }\end{array}$ & $\begin{array}{l}\text { Mean 4 } \\
\text { Bachelor's } \\
\text { Degree }\end{array}$ & $\begin{array}{c}\text { Mean 5 } \\
\text { Master's } \\
\text { Degree }\end{array}$ & $\begin{array}{c}\text { Observed Mean } \\
\text { Differences }\end{array}$ & p \\
3.82 & 3.00 & & & & .818 & .370 \\
3.82 & & 2.98 & & & .840 & .217 \\
3.82 & & & 3.68 & & .136 & .998 \\
3.82 & & & & 2.38 & 1.439 & $.009 *$ \\
\hline
\end{tabular}

*significant at the .05 level

Table 9 results reveal that there was a statistically significant difference between the level of education and having a local library or community center with computer lab access $(\mathrm{F}=$ 7.824, $d f=4 / 195, p>.05$ ) at the .05 level. The Scheffé results in Table 10 reveals that community residents who hold a master's degree were more likely to agree that there is enough access to community labs than community residents who had lesser degrees. 
6.7 Computer Classes

Table 11. Analysis of Variance Summary Table Impact of Level of Education on Computer Classes

\begin{tabular}{llccccc}
\hline & \multicolumn{1}{c}{$\begin{array}{c}\text { Source of } \\
\text { Variance }\end{array}$} & $\begin{array}{c}\text { Sum of } \\
\text { Squares }\end{array}$ & df & Mean Square & F & Sig. \\
Computer & Between Groups & 30.689 & 4 & 7.672 & 7.796 & $.000^{*}$ \\
Classes & Within Groups & 191.906 & 195 & .984 & & \\
& Total & 222.595 & 199 & & & \\
\hline
\end{tabular}

*significant at the .05 level.

Table 12. Scheffé Results of Computer Classes by Level of Education

\begin{tabular}{ccclccc}
\hline $\begin{array}{c}\text { Mean 1 } \\
\text { Completed } \\
\text { High }\end{array}$ & $\begin{array}{c}\text { Mean 2 } \\
\text { Some } \\
\text { College }\end{array}$ & $\begin{array}{c}\text { Mean 3 } \\
\text { Associate's } \\
\text { Degree }\end{array}$ & $\begin{array}{l}\text { Mean 4 } \\
\text { Bachelor's } \\
\text { Degree }\end{array}$ & $\begin{array}{c}\text { Mean 5 } \\
\text { Master's } \\
\text { Degree }\end{array}$ & $\begin{array}{c}\text { Observed } \\
\text { Mean } \\
\text { Differences }\end{array}$ & p \\
3.82 & 2.92 & & & & .898 & .185 \\
3.82 & & 2.92 & & & .895 & .096 \\
3.82 & & & 3.57 & & .250 & .967 \\
3.82 & & & & 2.45 & 1.370 & $.005^{*}$ \\
\hline
\end{tabular}

*significant at the .05 level.

Table 11 indicates the Analysis of Variance results for the impact of level of education on having a library or community center that offers technology classes. The data revealed that there is a statically significant difference among the groups $(\mathrm{F}=7.796, d f=4 / 195, p>.05)$ at the .05 level. Similarly, a Scheffé was run to determine where statically significant differences were. Mean differences were noted between community residents who completed high school and master's degrees. To be sure, residents with master's degrees were more likely to have a library or community center that offered technology classes. See Table 12 for these results. 
6.8 Empowerment through Technology

Table 13. Analysis of Variance Summary Table Impact of Level of Education on Empowerment through Technology

\begin{tabular}{llcrccc}
\hline & \multicolumn{1}{c}{$\begin{array}{c}\text { Source of } \\
\text { Variance }\end{array}$} & $\begin{array}{c}\text { Sum of } \\
\text { Squares }\end{array}$ & df & Mean Square & F & Sig. \\
Empowerment & Between Groups & 25.440 & 4 & 6.360 & 4.658 & $.001 *$ \\
through & Within Groups & 266.240 & 195 & 1.365 & & \\
Technology & Total & 291.680 & 199 & & & \\
\hline
\end{tabular}

*significant at the .05 level.

Table 13 reveals the results of community residents' perception of level of education and empowerment to become computer literate and learn how to use the technology to fight encroachment of hazardous waste facilities and address other community needs. Statistically significant differences were found between the means of educational level and empowerment through technology $(\mathrm{F}=4.658, d f=4 / 195, p>.05)$ at the .05 level.

Table 14. Scheffé Results of Empowerment through Technology by Level of Education

\begin{tabular}{ccccccc}
\hline $\begin{array}{c}\text { Mean 1 } \\
\text { Completed } \\
\text { High } \\
\text { School }\end{array}$ & $\begin{array}{c}\text { Mean 2 } \\
\text { Some } \\
\text { College }\end{array}$ & $\begin{array}{c}\text { Mean 3 } \\
\text { Associate's } \\
\text { Degree }\end{array}$ & $\begin{array}{c}\text { Mean 4 } \\
\text { Bachelor's } \\
\text { Degree }\end{array}$ & $\begin{array}{c}\text { Mean 5 } \\
\text { Master's } \\
\text { Degree }\end{array}$ & $\begin{array}{c}\text { Observed } \\
\text { Mean } \\
\text { Differences }\end{array}$ & p \\
3.45 & 3.32 & & & & .135 & .999 \\
3.45 & & 2.95 & & & .509 & .760 \\
3.45 & & & 3.43 & & .023 & 1.000 \\
3.45 & & & & 2.34 & 1.110 & .131 \\
\hline
\end{tabular}

*significant at the .05 level.

While the Scheffé showed no statistically significant difference between the groups, there were mean differences (1.087) between groups of community residents with an bachelor and master degrees $\left(.006^{*}\right)$. The results reveal that residents with bachelor and masters degrees perceived that their level education empowered to utilize technology than more than residents with high school, some college or associate degrees.

\section{Discussion and Conclusion}

Research has demonstrated that there indeed is a strong need for university-community partnerships. Most significantly, these partnerships need to be galvanized to address the ever 
growing problem of environmental injustice. Indeed, these partnerships should not be limited to communities within close proximity to a university, but should serve as broad base to other communities. One of the most significant findings of the present study pertained to the perceptions of residents' level of education and exposure to environmental waste. To be sure, the respondents perceived that residents with less than an associate's degree were more likely to live in a community with hazardous waste. These findings are consistent with those of Kearney and Kiros (2009), Norton et al. (2007) and Martuzzi et al. (2010). The aforementioned researchers reported that there is a relationship between wealth, education and environmental waste. A plausible reason for this is level of education tends to determine socioeconomic status and personal wealth.

Another noteworthy finding of the present study was associated with level of education and preventive technology. These findings revealed that community residents with education levels of high school, some college and an associate's degree perceived that technology was not used to prevent their communities from being targeted for environmental waste. These findings parallel those of Rao (2005) and Elbert and Alston (2005).

An interesting finding of this study was the impact of level of education on community resources to include university partnerships. Only community members with master's degrees perceived that education level did make a difference in whether or not the community had a university partnership and access to all other resources. These findings were consistent with those of Bombyk et al. (2003), Young (1995), Campbell \& Fainstein (2003) and Reardon (2005). Indeed, a reasonable explanation for the current finding may be that residents with advanced degrees are more exposed to the types of resources and funding those university-community partnerships can provide.

Interestingly, the finding revealed that community members from all levels of education but bachelor's degree perceived that level of education directly influenced their ability to have access to technology away from work. This finding is mirrored by research by Bryant, Bunyan \& Mohai (1992), Rao (2005), Mayfield and Lucas (2000) and Elbert and Alston (2005). The researchers indicate that education is relevant in personal access to technology and that there is still a gap in digital access.

The findings of level of education on having a community center or library that offered technology classes mirrored the of preventive technology. Only residents with master's degrees perceived that there was a relationship between level of education and a community center or library. Likewise, residents with bachelor and master's degrees aligned empowerment through technology with their level of education.

\section{References}

Baibergenova, A., Kudyakov, R., Zdeb, M., \& Carpenter, D. O. (2003). Low birth weight and residential proximity to PCB-contaminated waste sites. Environmental Health Perspect., 11, 352-7. http://dx.doi.org/10.1289/ehp.6053

Bombyk, M., Ohren, J. \& Shue, L. (2003). University Employees Who Live Locally: the Town-Gown Divide. Metropolitan Universities, 14(4), 22-28. 
Bryant, B., \& Mohai. (1992). Race and the incidence of environmental hazards: A time for discourse. Boulder, Colorado: Westview Press.

Bullard, R., Mohai, P., Saha, R., \& Wright, B. (2007). Toxic wastes and race at twenty 1987-2007: Grassroots struggles to dismantle environmental racism in the United States (Annual Report). Cleveland, OH: The United Church of Christ.

Bullard, R. (2000). Dumping in Dixie: Race, class, and environmental quality (3rd ed.). Boulder, Colorado: Westview Press.

Campbell, S., \& Fainstein, S. (2003). Readings in planning theory (2nd ed.). Blackwell Publishing Ltd.: UK.

Cole, L. W., \& Foster, S. (2001). From the ground up: Environmental racism and the rise of the environmental justice movement. New York: New York City Press.

Cutter, S., Holm, D., \& Clark, L. (1996). The role of geographic scale in monitoring environmental justice. Risk Analysis, 16(4), 517-526. http://dx.doi.org/10.1111/j.1539-6924.1996.tb01097.x

Damery, S., Petts, J., Walker, G., \& Smith, G. (2007). Addressing environmental inequalities: Waste management. Bristol: United Kingdom. Environment Agency.

Davidoff, P. (1965). Advocacy and Pluralism in Planning, JAW. Social Planning, 31(4), 331-337.

Elbert, C., \& Alston, A. (2005). An evaluative study of the United States cooperative extension service's role in bridging the digital divide. Journal of Extension, 43(5). Retrieved from http://www.joe.org/joe/2005october/rblp.shtml

Elliott, P., Richardson, S., Abellan, J. J., Thomson, A., de Hoogh, C., Jarup, L., \& Briggs, D. J. (2009). Geographic density of landfill sites and risk of congenital anomalies in England. Occupational and Environmental Medicine, 61-9. http://dx.doi.org/10.1136/oem.2007.038497

Isaac, J. (2003). Advocacy in Action: Council for International Development Resource Kit. Retrieved from http://www.cid.org.nz-training-advocacy.pdf

Kearney, G., \& Kiros, G. E. (2009). A spatial evaluation of socio demographics surrounding national priorities list sites in Florida using a distance-based approach. International Journal of Health Geography, 17(8), 33. http://dx.doi.org/10.1186/1476-072X-8-33

Marshall, C., \& Rossman, G. (2011). Designing Qualitative Research (5th ed.). Thousand Oaks, CA: Sage Publications.

Martuzzi, M., Mitis, F., \& Forasteire, F. (2010). Inequalities, inequities, environmental justice in waste management and health. European Journal of Public Health, 20(1), 21-26.http://dx.doi.org/10.1093/eurpub/ckp216

Mayfield, L., \& Lucas, E. P. (2000). Mutual Awareness, Mutual Respect: The Community 
and the University Interact. Cityscape: A Journal of Policy Development and Research, 5(1), 173-184.

Norton, J. M., Wing, S., Lipscomb, H. J., Kaufman, J. S., Marshall, S. W. \& Cravey, A. J. (2007). Race, wealth, and solid waste facilities in North Carolina. Environmental Health Perspect, 115, 344-50. http://dx.doi.org/10.1289/ehp.10161

Oakes, J., Anderton, D., \& Anderson, A. (1996). A longitudinal analysis of environmental equity in communities with hazardous waste facilities. Social Science Research, 25(0006). 125-148. http://dx.doi.org/10.1006/ssre.1996.0006

Onyx, J. (2008). University community engagement: What does it mean? Gateways: The International Journal of Community Research and Engagement, 1, 90.

Reardon, K. (2005). Straight As? Evaluating the success of community university development partnerships. Communities \& Banking, 3-10.

Rao, S. (2005). Bridging the digital divide: Efforts in India. Telematics and Informaties, 22, 361-375.

from

http://www.sciencedirect.com/science/article/pii/S0736585305000195

Reid, J. N. (2000). Community Participation: How People Power Brings Sustainable Benefits to Communities. USDA Rural Development. Office of Community Development.

Rowson, J., Broome, S., \& Jones, A. (2010). Connected communities: How social networks power and sustain the Big Society, Royal Society for the encouragement of the Arts, Manufactures and Commerce (RSA). Retrieved from www.thersa.org/projects/connectedcommunities

Saint, P. M., Flavell, R. J., \& Fox, P. F. (2009). NIMBY wars: The politics of land use. Saint University Press: Hingham, MA.

U.S. Census Bureau. (2010). Profile of general demographic characteristics. Washington, DC: U.S. Government Printing Office.

U.S. Department of Environmental Protection Agency. (n.d). About EPA. Retrieved from http://www.epa.gov/epahome/aboutepa.htm

U.S. Department of Environmental Protection Agency. (n.d). Criminal Enforcement.

Young, W. (1995). University-Community Partnerships: Why Bother? Metropolitan Universities, 6(3), 71-77.

\section{Copyright Disclaimer}

Copyright reserved by the authors.

This article is an open-access article distributed under the terms and conditions of the Creative Commons Attribution license (http://creativecommons.org/licenses/by/3.0/). 